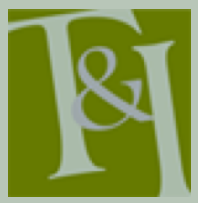

The International Journal for Translation \& In erpreting Research trans-int.org

\section{Middling-status profession, high-status work: Finnish translators' status perceptions in the light of their backgrounds, working conditions and job satisfaction}

Minna Ruokonen

University of Eastern Finland

minna.ruokonen@uef.fi

Jukka Mäkisalo

University of Eastern Finland

jukka.makisalo@uef.fi

DOI: 10.12807/ti.110201.2018.a01

\begin{abstract}
This article explores how Finnish professional translators perceive the status of the profession in general as opposed to the status of their own work, and how these status perceptions are affected by various factors. We first consider the multiple meanings of status, summarize previous empirical research and introduce the Finnish context, and then go on to statistically analyze survey data consisting of Finnish business, literary and audiovisual translators' responses $(n=450)$. The analysis reveals that the respondents rank translator status in general as middling (as in previous research) but, at the same time, see the status of their own work as high. Further analysis indicates that while status perceptions of the profession in general are mostly not linked to the respondents' working conditions or job satisfaction, perceptions of the status of one's own work fluctuate more. Interestingly, the respondents' backgrounds and qualifications fail to produce statistically significant differences. Moreover, the role of some factors varies among business, literary and audiovisual translators. Distinguishing between the status of the profession in general and the status of the respondents' work thus appears to be important for a better understanding of status and may even partly explain why a middling-status profession nevertheless fosters satisfied translators.
\end{abstract}

Keywords: Status, prestige, working conditions, job satisfaction, professional translators

\section{Introduction}

At a first glance, status perceptions may appear of little consequence to translation practice: studying how translators perceive the value, respect or prestige accorded to their profession hardly leads to direct improvements in the working environment. Nevertheless, perceptions matter. Feeling undervalued at work can make employees less motivated and more likely to change jobs (American Psychological Association, 2012). Status perceptions and the factors linked to them are thus relevant to translators' professional wellbeing and to translation practice.

Translation \& Interpreting Vol 10 No 1 (2018) 
The present article was inspired by a paradox: while the translator's profession apparently enjoys only a middling status (see Section 2 for details), translators themselves appear to be quite satisfied with their job (see overview in Dam \& Zethsen, 2016). We believe that this paradox stems from the multiple meanings of "status", more specifically the perceived prestige and value of the profession in general as opposed to that of an individual translator's own work.

We aim to explore translators' perceptions of these two meanings of status in order to discover if any differences emerge, particularly due to variation in the respondents' backgrounds, working conditions and job satisfaction. Our data come from a survey conducted among Finnish translators in 2014 with 450 respondents, partly replicating Helle V. Dam and Karen Korning Zethsen's status surveys among Danish translators (see Section 2 below).

In what follows, Section 2 clarifies the various meanings of status and presents a review of previous research. Section 3 then describes the Finnish respondents' context, and Section 4 moves on to the design of the survey and the variables analyzed. The results of the statistical analysis are reported in Section 5, followed by a discussion and conclusions in Section 6 .

\section{Previous research}

Within Translation Studies, empirical research into translator status has only been conducted for less than a decade (see overview in Ruokonen, 2013), but includes major projects such as Helle V. Dam and Karen Korning Zethsen's surveys of 307 Danish translators $(2008,2011,2012)$ and David Katan's (2009) international survey of 890 translation/interpreting (T/I) professionals, teachers and students. Furthermore, as pointed out by Ruokonen (2013), implications for status can be found in studies on translators' role, identity or habitus, notably Rakefet Sela-Sheffy and Miriam Shlesinger's research on the identity of Israeli translators and interpreters, with data comprising over 200 media texts (e.g. Sela-Sheffy, 2008, 2010) and 95 interviews (e.g. Sela-Sheffy, 2016). Recently, research into translator status has also been covered in a special issue of the Journal of Specialised Translation (e.g. Dam \& Zethsen, 2016; Ruokonen, 2016; Sela-Sheffy, 2016) and at a panel at the 2016 Congress of the European Society for Translation Studies (Ruokonen, Svahn \& Salmi, 2016).

Status has thus become a major topic within sociologically oriented translation research, but the concept itself remains ambiguous. Previous research distinguishes at least the following meanings:

- The status of a profession: fulfilling the criteria of a specialized and protected occupation that is highly valued by society (Volti, 2008, p. 97-102). Translation is often considered a semi-profession that fails to meet all such criteria (e.g. Sela-Sheffy, 2006, 2016);

- Socio-economic status of an occupation: calculated on the basis of income level and education; can be used to predict occupational prestige (Treiman, 2001, p. 300-301; Ganzeboom \& Treiman, 2003);

- Occupational prestige: subjective perceptions of value and respect attached to an occupation, typically studied within sociology by means of rankings gathered from among the general population (e.g. Volti, 2008, p. 171-173; Treiman, 2001, p. 299-300; Gentile, 2013, 
p. 65-67). Within translation research, in contrast, prestige rankings typically come from translators and interpreters themselves.

- Status as market value: Pym et al. (2012, p. 11-12; 2016, p. 33) define status as the value produced by signals indicating expertise and trustworthiness in the translation market, such as academic qualifications or memberships of professional associations. They further observe that this kind of status is related to professional exclusion (i.e., the status of a profession) and to prestige (Pym et al., 2012, p. 13);

- The status of an individual: the position of a person in a social structure (Scott, 2014, s.v. status); in translation research, the position that an individual translator or interpreter negotiates him- or herself in a particular situation (Wadensjö, 2011, p. 143).

As can be seen, the different aspects of status are linked to each other in a number of ways and are not always easily distinguishable. Studies may also explore several aspects of status simultaneously (Ruokonen, 2013, p. 328).

The present article focuses on translators' perceptions and experiences of, firstly, the prestige and value of the translation profession in general and, secondly, the prestige and value of an individual translator's work, or the notion of how highly one's work is appreciated in one's working environment by one's employers or commissioners. The first aspect matches that of occupational prestige as defined above and by Dam and Zethsen (e.g. 2008) and Ruokonen (2016). The second aspect falls in between occupational prestige and Wadensjö's notion of the status of an individual negotiated in a situation, as it represents an individual's perception of his/her long-term prestige in a particular context. Both aspects can be argued to influence translators' self-perceptions, job satisfaction and motivation and, hence, professional wellbeing.

Previous translation research has focused on the status of the profession in general. In this sense, status is perceived as middling or low by translators and translation students, regardless of the scales used (Dam \& Zethsen, 2011, 2012; Katan, 2009; Ruokonen, 2016). Translator prestige seems to be lower than that of interpreters (Dam \& Zethsen, 2013; Katan, 2009; Setton \& Guo Liangliang, 2011, p. 104). There are also implications of literary translators' higher prestige (e.g. Sela-Sheffy, 2010), but no quantitative empirical evidence.

Factors correlating with the perceived status of the profession have mainly been studied by Dam and Zethsen, who have focused on four parameters: income, education/expertise, visibility, and power/influence. Their findings highlight the following results:

- Translators working in different positions and environments may have different status perceptions. Danish in-house translators at nontranslational companies had higher status rankings than freelancers or in-house translators at translation agencies (Dam \& Zethsen, 2011, p. 984);

- A certain level of income seems to be a necessary but not in itself sufficient condition for a high-status ranking. While Danish

\footnotetext{
${ }^{\mathrm{i}}$ As the issue of whether translation is an occupation or a profession is not the focus of this article, we use the more common term 'translation profession'.
} 
company translators with low incomes were prone to low-status rankings, EU translators and freelancers with high incomes did not report correspondingly higher status rankings (Dam \& Zethsen, 2009, p. 15 ; 2011, p. 986 ; 2012, pp. 221-222);

- Translators feel that people outside the profession fail to appreciate the education and expertise required to translate (Dam \& Zethsen, 2008, p. 86-88, 2011, p. 988; 2013, p. 245-246; cf. Setton \& Guo Liangliang, 2011, p. 105-106);

- A sense of invisibility or distance from decision-making may contribute to lower status rankings (Dam \& Zethsen, 2011, p. 991$992 ; 2012$, p. $226 ; 2013$, p. 247-248).

As can be seen, translators' backgrounds and working conditions were covered to some extent, but professional wellbeing was not, unless the concept is extended to a sense of invisibility. The only demographic factor that played a role in status rankings was age: company translators' low-status answers tended to increase with age (Dam \& Zethsen, 2009, p. 7).

Paradoxically, these perceptions of middling prestige and lack of appreciation are accompanied by a sense of job satisfaction and commitment to the field (Katan, 2009, 147-149; Setton \& Guo Liangliang, 2011, p. 101102; Dam \& Zethsen, 2016, p. 176-177). Previous research links this paradox to the rewarding nature of translation itself (Katan, 2009, p. 148-149; Dam \& Zethsen, 2016, p. 180), but, as our results will indicate, it may also reflect the respondents' sense of the high status of their own work. To understand status perceptions more fully, we will therefore investigate translators' perceptions of the status of the profession in general versus their perceptions of the status of their own work and analyze their links to translators' backgrounds, working conditions and job satisfaction. Next, however, a few words are in order about the Finnish context and professional translation in Finland.

\section{The Finnish context}

Translation plays a major role in Finns' everyday lives. Studies suggest that at least a third of the texts read on a daily basis are translations (Mäkisalo, 2006; Salmi, 2010). This is due to two main factors: firstly, Finnish is globally a minority language, spoken by approximately five million people, or $89 \%$ of Finland's population (Statistics Finland, 2015a). Secondly, as Finland has two official languages, all official documents must be made available in both Finnish and Swedish and civil servants must provide services in both languages. ${ }^{\text {ii }}$ Finland's membership in the European Union in 1995 also increased the demand for translations. Of the foreign languages in Finland, Russian has the most native speakers (about 1.3\% of the population), followed by Estonian and English (Statistics Finland, 2015a; Statistics Finland, 2015b). The most widely learned and used foreign language in schools, business and the media is English (Leppänen et al., 2011, p. 17-20).

The first professional translators' association, The Finnish Association of Translators and Interpreters, was established in 1955. It brings together business, audiovisual and literary translators, particularly freelancers, as well as interpreters, translation teachers and researchers. Salaried business

\footnotetext{
ii In practice, the native speakers of Swedish only constitute ca. $5 \%$ of the population (Statistics Finland, 2015a) along the southern and western coasts.
} 
translators have had a trade organization since 1979, currently known as Translation Industry Professionals KAJ. Both associations remain active and influential, with some 3,000 translator members. ${ }^{\text {iii }}$ Considering that $18 \%$ of our survey respondents belonged to neither association, the actual number of professional translators in Finland is probably closer to 4,000.

Finnish translator training is also well established: it was institutionalized in the 1960s and transferred to universities in 1981. Translation programs are mainly intended for native speakers of Finnish. The other working languages covered are English, French, German, Italian, Russian, Spanish and Swedish.

As in most countries, the translator's profession is not protected in Finland, and anyone can try their hand at translation. The only exception are the so called "authorized translators" of official documents. The links between authorization and status are explored in another article (Ruokonen, forthcoming).

Recent trends in the Finnish translation market have been less than positive. Similarly to developments elsewhere (e.g. Pym et al., 2012, p. 8889), Finnish translators increasingly work as freelancers, and their work has been seriously affected by outsourcing and competitive tendering. In business translation, the criteria for public tenders can be so exhaustive as to exclude freelancers and small to middle-sized businesses. Competitive tendering has also reportedly resulted in lower fees and poor quality (Antinjuntti et al., 2014). In audiovisual translation, two decades of competitive tendering and outsourcings have led to a situation where translators mostly work as subcontractors for multinational companies and suffer from unstable working conditions and low fees (Abdallah, 2007; Tuominen, 2015).

Finnish literary translators have traditionally worked as freelancers and hence have not been subject to outsourcing. However, in recent years their fees, never high, have fallen to the point where a full-time literary translator's income can amount to less than $€ 1,000$ per month (Ruokonen, 2016, p. 195$196)$, or under half of the national median income ( $€ 24,000$ per year; Statistics Finland, 2015c).

On the one hand, translation thus plays a major role in Finnish society, and Finnish translator training and associations are well-established. On the other hand, particularly audiovisual and literary translators' working conditions were hardly ideal when the survey was distributed. It remains to be seen how these factors are reflected in the respondents' status perceptions.

\section{Method and data}

The survey partly replicates Dam and Zethsen's $(2008,2011)$ questionnaires for Danish company, freelance and agency translators (see Section 2 above), provided for our use by Dam and Zethsen. Having been translated into Finnish by an experienced professional translator, these three questionnaires were merged into a single questionnaire and adapted to the Finnish context by Minna Ruokonen with regard to, for example, educational background and income levels. The questionnaire was also expanded to gather data on translators' working conditions and job satisfaction. The resulting draft included 50 to 60 items, depending on each respondent's situation. 10 items concerned background information, and the rest covered status, Dam and Zethsen's four status parameters (income, education/expertise, visibility, and

iii Estimated on the basis of the associations' websites. 
power/influence), as well as working conditions and job satisfaction. In the present article, we focus on the dependencies between status perceptions and background factors, working conditions, and job satisfaction.

Status perceptions were approached through two distinct items. The status of the profession was addressed by the item "To what degree is the translator's occupation valued in Finland". Unlike the corresponding Danish item, the Finnish formulation did not mention the word 'status' (in Finnish, asema), which would have been too ambiguous (Ruokonen, 2016, p. 194). Instead, the item follows a wording common in Finnish surveys of occupational status (ibid.). The item on the status of the individual respondent's work was displayed either as "To what degree is your own work valued at your workplace" (employee respondents) or "To what degree is your own work valued by commissioners" (freelancer respondents). These formulations are similar to the corresponding Danish items.

All status items offered five verbal alternatives on the Likert scale, which in the analysis correspond to figures 1 to 5 as follows:

- $1=$ To a very low degree or not at all

- 2 = To a low degree

- 3 = To a certain degree

- 4 = To a high degree

- $5=$ To a very high degree.

These alternatives were equivalent to the Danish ones; as in Dam and Zethsen's questionnaires, they were given in the reverse order so as not to prime the respondents to choose the lowest ranking (Dam \& Zethsen, 2008, p. 78).

The online questionnaire was created by using a well-established licensed application called E-lomake (https://e-lomake.fi/web/briefly-in-english.html). The questionnaire was commented on and tested by colleagues (Leena Salmi, Tiina Tuominen, Taru Virtanen) and three professional translators. After some final amendments, the link to the online questionnaire was distributed through the two major translator associations' mailing lists, as well as social media, in October/November 2014. To encourage responses, five gift certificates to a national chain of bookstores were raffled. By 12 December, a total of 457 responses had been collected; after excluding duplicates and those only participating in the raffle, 450 responses remained to be analyzed.

In the analysis, we created cross-tabulations relating dependent variables (perceived status of the profession in general; perceived status of the respondent's own work) to the independent variables (background, working conditions and job satisfaction; see Table 1 below). We then calculated whether the independent variables produced significant differences in the distributions of responses in the two status items. Statistical significance was calculated by the Chi Square test; values under .05 are statistically significant. Differences are also illustrated by means of frequencies and means. Most of the calculations were performed by Minna Ruokonen and reviewed by Jukka Mäkisalo, except for income level, where the process was reversed.

The independent variables can be roughly divided into two groups, illustrated in Table 1 below, with comments on whether the variable was addressed in Dam and Zethsen's studies. 
Table 1: Independent variables considered in the analysis

\begin{tabular}{|c|c|}
\hline Variable & $\begin{array}{l}\text { Addressed by Dam and } \\
\text { Zethsen }\end{array}$ \\
\hline \multicolumn{2}{|l|}{ A) Background } \\
\hline Age & Yes \\
\hline Gender & Yes \\
\hline $\begin{array}{l}\text { Education/qualifications: } \\
\text { - Degree level (MA, BA, other); } \\
\text { - Major subject (translation, foreign languages or } \\
\text { Finnish/Swedish, other); } \\
\text { - Possession of the Finnish authorized } \\
\text { translator's qualification }\end{array}$ & $\begin{array}{l}\text { The majority of the } \\
\text { respondents were Danish } \\
\text { business translators with an } \\
\text { MA in specialized } \\
\text { translation and/or state } \\
\text { certification (Dam \& } \\
\text { Zethsen, } 2011 \text {, p. } 982 \text { ). }\end{array}$ \\
\hline Length of work experience & Yes \\
\hline $\begin{array}{l}\text { Specialization: audiovisual, business or literary } \\
\text { translation }\end{array}$ & $\begin{array}{l}\text { Studies focused on } \\
\text { business translators and } \\
\text { interpreters }\end{array}$ \\
\hline \multicolumn{2}{|l|}{ B) Working conditions and job satisfaction } \\
\hline $\begin{array}{l}\text { Employment status: employed/salaried vs. } \\
\text { freelancer/entrepreneur vs. unemployed or } \\
\text { working in a field other than translation }\end{array}$ & $\begin{array}{l}\text { Employed and freelance } \\
\text { translators surveyed } \\
\text { separately; no unemployed } \\
\text { respondents }\end{array}$ \\
\hline $\begin{array}{l}\text { Income: } \\
\text { - Actual income level; } \\
\text { - Satisfaction with one's income level }\end{array}$ & $\begin{array}{l}\text { - Actual income level: Yes } \\
\text { - Satisfaction: No }\end{array}$ \\
\hline $\begin{array}{l}\text { Compromising one's quality standards: } \\
\text { - Frequency of having to compromise translation } \\
\text { quality due to external factors such as deadlines }\end{array}$ & No \\
\hline $\begin{array}{l}\text { Stress: } \\
-\quad \text { Frequency of experiencing work-related, } \\
\text { negative stress }\end{array}$ & No \\
\hline $\begin{array}{l}\text { Changing careers: } \\
\text { - Frequency of thinking about leaving translation } \\
\text { for another field of business. }\end{array}$ & No \\
\hline
\end{tabular}

As Table 1 illustrates, while the Danish surveys focused on trained business translators, we hoped to produce a broader description of Finnish translators with different backgrounds, specializations and working contexts. Items on translators' professional wellbeing and job satisfaction were also added.

Table 2 shows selected background data. On the basis of the numbers of members in the Finnish translators' associations (see Section 3 above), the respondents represent ca. $10 \%$ of Finnish professional translators. Business translators are probably the best represented; the number of literary translator respondents is also quite good compared to the numbers of respondents in recent fee inquiries ${ }^{\text {iv. }}$ Among the audiovisual translators, the response rate could have been higher, which may be due to survey fatigue: earlier, in 2014,

iv From 2010 to 2014, the number of responses to literary translators' fee inquiries varied from 81 to 115 (information retrieved from a members-only website). 
Table 2: Respondents' backgrounds

\begin{tabular}{|c|c|c|}
\hline & $\mathbf{N}$ & $\%$ \\
\hline \multicolumn{3}{|l|}{ Specialization } \\
\hline Audiovisual translator & 57 & 12.7 \\
\hline Business translator & 269 & 59.8 \\
\hline Literary translator $^{\mathrm{v}}$ & 71 & 15.8 \\
\hline Other $^{\mathrm{v}}$ & 53 & 11.8 \\
\hline Total & 450 & 100.0 \\
\hline \multicolumn{3}{|l|}{ Form of employment } \\
\hline Employed & 137 & 30.4 \\
\hline Freelancer/entrepreneur ${ }^{\mathrm{VII}}$ & 260 & 57.8 \\
\hline $\begin{array}{l}\text { Unemployed, studying, working in another field } \\
\text { than translation }\end{array}$ & 53 & 11.8 \\
\hline Total & 450 & 100.0 \\
\hline \multicolumn{3}{|l|}{ Gender } \\
\hline Male & 79 & 17.6 \\
\hline Female & 362 & 80.4 \\
\hline $\mathrm{N} / \mathrm{A}$ & 9 & 2.0 \\
\hline Total & 450 & 100.0 \\
\hline \multicolumn{3}{|l|}{ Work experience in $T / /$ industry } \\
\hline 5 years or less & 102 & 22.7 \\
\hline 6 to 10 years & 83 & 18.4 \\
\hline 11 to 15 years & 82 & 18.2 \\
\hline 16 to 20 years & 65 & 14.4 \\
\hline 21 years or more & 118 & 26.2 \\
\hline Total & 450 & 100.0 \\
\hline \multicolumn{3}{|l|}{ Education } \\
\hline $\begin{array}{l}\text { Degree from high school, vocational training or a } \\
\text { university of applied sciences }\end{array}$ & 3 & 0.7 \\
\hline Diploma in translation ${ }^{\text {vil }}$ & 22 & 4.9 \\
\hline University courses & 29 & 6.4 \\
\hline Bachelor's degree & 52 & 11.6 \\
\hline Master's degree & 336 & 74.7 \\
\hline Doctoral or licentiate's degree ${ }^{\mid x}$ & 8 & 1.8 \\
\hline Total & 450 & 100.0 \\
\hline
\end{tabular}

another researcher had conducted a major study on audiovisual translators' income (Hietamaa, 2014). The proportion of freelancers (over half of the respondents) vs. employed translators (almost a third) is probably fairly

v In the questionnaire, this alternative was given as "literary translator, Finnisher". A "Finnisher" or suomentaja typically refers to literary translators but also covers translators of non-fiction books. However, only 7 respondents specified being nonfiction "Finnishers".

vi Those who chose this alternative mostly described themselves as "multipurpose translators" $(\mathrm{n}=18)$, "interpreters" $(\mathrm{n}=10)$ or "languages/communications specialists" $(\mathrm{n}=9)$.

vii These were mainly one-person businesses. Only 9 respondents had paid employees, mostly one per business.

viii In Finnish, diplomikielenkääntäjä, a degree issued by language institutes before translator training was incorporated into universities in 1981.

ix A licentiate's degree is a research degree completed after a master's degree and before a doctorate. 
representative. Overall, the data highlight the experiences of professionals with university degrees and extensive working experience, although the younger generation is also sufficiently represented.

\section{Results}

The overall mean value of the status of the profession was 2.55 on a scale of 1 to 5, or just below the midpoint. This is similar to Katan's results (2009) and almost identical with some Danish translators' average status rankings (Dam \& Zethsen, 2011, 2012). In contrast, when we look at the respondents' perceived status of their own work ${ }^{x}$, it is significantly higher, as illustrated by Figure 1 below:

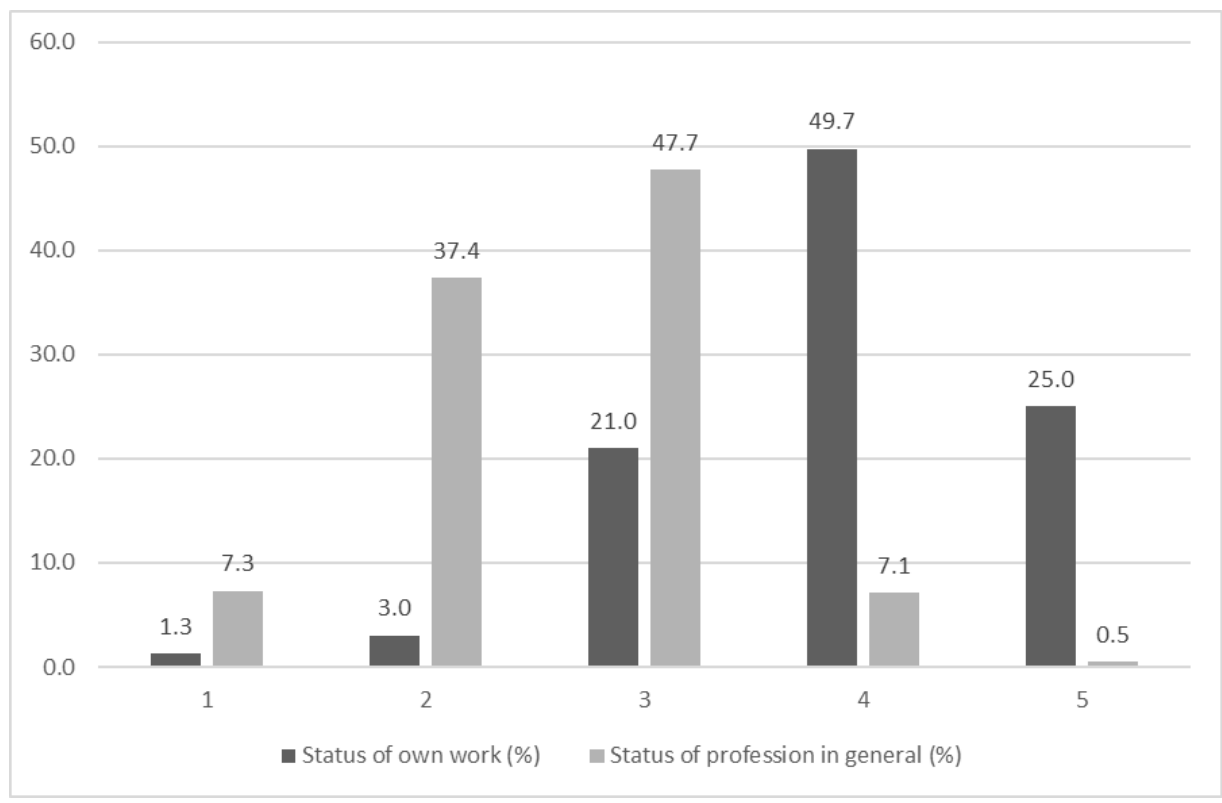

Figure 1: Status rankings (\%) of one's own work vs. of the profession in general

The rankings 1 to 5 correspond to verbal alternatives as specified in Section 4 above. The mean ranking for status of one's own work is 3.94, meaning that the respondents feel their own work to be valued "to a high degree". The difference between the two status rankings is statistically very highly significant $(p<.001)$. In other words, while the respondents feel that translators' work in general is not very highly valued, they do feel respected and valued in their immediate professional context.

We next consider which aspects of the respondents' backgrounds and working conditions produce statistically significant differences in the respondents' status perceptions.

\footnotetext{
${ }^{\mathrm{x}}$ There were 396 responses to this item, as it was not shown to respondents who were unemployed or not working as translators at the time of the survey.
} 


\subsection{Status and specialization: mixed results}

As literary translators are often thought to enjoy higher status than other translators, we wanted to see if our respondents would agree. The respondents were requested to select the three translatorial professions they believed were the most highly valued in Finland. This yielded a total of 1180 'ticks', or 2.62 per respondent. The professions were then ordered by the number of 'ticks' and ranked based on statistical significance (Chi Square with Yates' correction between each category and its closest neighbor). This produced the list in Table 3 below:

Table 3: The respondents' ranking of translatorial professions

\begin{tabular}{|l|l|l|}
\hline & & $\mathbf{n}$ \\
\hline 1. & Conference interpreter & 372 \\
\hline 2. & Literary translator & 332 \\
\hline 3. & Business translator & 160 \\
\hline \multirow{2}{*}{ 4. } & Community interpreter & 127 \\
\hline \multirow{2}{*}{5.} & Technical writer & 82 \\
\cline { 2 - 3 } & Audiovisual translator & 76 \\
\hline \multirow{2}{*}{6.} & Localizer & 17 \\
\cline { 2 - 3 } & Translation coordinator & 14 \\
\hline & Total & 1180 \\
\hline
\end{tabular}

Thus, literary translators were thought to enjoy higher status than business and audiovisual translators. Similarly to previous research (Katan, 2009, p. 126; Dam \& Zethsen, 2013, p. 241-242), (conference) interpreters were also considered to rank highly.

The rankings in Table 3 suggest that the respondents' specializations could produce differences in their status perceptions. However, this turned out not to be the case. The mean values for status in general vary from 2.51 (audiovisual translators) to 2.62 (literary translators), but this is not statistically significant (lowest $p=.194$ ). Similarly, the mean values for the status of one's own work vary from 3.71 (audiovisual translators) to 3.97 (literary translators) and 4.00 (business translators), but again, the differences are not statistically significant $(p=.469)$. Thus, while the respondents believe that translators in general are not highly valued in society and that literary translators enjoy higher esteem than other translators, they still all feel appreciated in their own professional context.

\subsection{Income and satisfaction with income}

The respondents' gross median income was $€ 32,000$ per year for the employed translators and $€ 31,800$ for the freelancers, which is above Finnish households' median gross income (ca. €24,000; Statistics Finland, 2015c) and corresponds to about $€ 2,600$ per month. The medians varied by specialization, being $€ 39,000$ for business translators, $€ 33,000$ for audiovisual translators and $€ 19,500$ for literary translators; literary translators' income was thus considerably lower than that of the other translators.

To explore the links between income and status perceptions, we divided the respondents into two income groups: below the median ("low income") and above the median ("high income"). Comparing the status rankings of these two income groups showed that the general status rankings are not linked to income, either in the overall data $(p=.487)$, or when the employed 
$(p=.273)$ and freelancers $(p=.609)$ are considered separately. However, there is a connection between income and the status of one's own work: the freelancer respondents with below-median income judged the status of their own work significantly lower than the freelancer respondents with above-median incomes $(p=.033)$. For the employed translators, in contrast, this dependency is insignificant $(p=.281)$.

Concerning satisfaction with one's income, further differences emerge based on the respondents' specialization. Table 4 below shows the mean status rankings and $p$ values for the respondents with different specializations in relation to their satisfaction with their income. As the table shows, satisfaction with one's income produces statistically significant differences among business translators (for both status in general and the status of one's own work) and among audiovisual translators (though only concerning the status of one's own work) but not among literary translators.

Table 4: Mean status values (on a scale of 1 to 5) and their dependency on satisfaction with income

\begin{tabular}{|c|c|c|c|c|}
\hline & \multicolumn{3}{|c|}{ Mean status: profession in general } & \multirow[b]{2}{*}{$\begin{array}{l}p \text { value for } \\
\text { dependency } \\
\text { between status } \\
\text { in general and } \\
\text { job satisfaction }\end{array}$} \\
\hline & $\begin{array}{l}\text { Very or } \\
\text { somewhat } \\
\text { dissatisfied } \\
\text { with one's } \\
\text { income }\end{array}$ & $\begin{array}{l}\text { Neither } \\
\text { satisfied nor } \\
\text { dissatisfied } \\
\text { with one's } \\
\text { income }\end{array}$ & $\begin{array}{l}\text { Somewhat or } \\
\text { very satisfied } \\
\text { with one's } \\
\text { income }\end{array}$ & \\
\hline $\begin{array}{l}\text { Audiovisual } \\
\text { translators }\end{array}$ & 2.32 & 2.33 & 2.65 & $\begin{array}{l}198 \\
\text { Not significant }\end{array}$ \\
\hline $\begin{array}{l}\text { Business } \\
\text { translators }\end{array}$ & 2.35 & 2.54 & 2.71 & $\begin{array}{l}.025 \\
\text { Significant }\end{array}$ \\
\hline \multirow[t]{3}{*}{$\begin{array}{l}\text { Literary } \\
\text { translators }\end{array}$} & 2.58 & 2.75 & 2.72 & $\begin{array}{l}.432 \\
\text { Not significant }\end{array}$ \\
\hline & \multicolumn{3}{|c|}{ Mean status: one's own work } & \\
\hline & $\begin{array}{l}\text { Very or } \\
\text { somewhat } \\
\text { dissatisfied } \\
\text { with one's } \\
\text { income }\end{array}$ & $\begin{array}{l}\text { Neither } \\
\text { satisfied nor } \\
\text { dissatisfied } \\
\text { with one's } \\
\text { income }\end{array}$ & $\begin{array}{l}\text { Somewhat or } \\
\text { very satisfied } \\
\text { with one's } \\
\text { income }\end{array}$ & $\begin{array}{l}p \text { value for } \\
\text { dependency } \\
\text { between status } \\
\text { of one's own } \\
\text { work and job } \\
\text { satisfaction }\end{array}$ \\
\hline $\begin{array}{l}\text { Audiovisual } \\
\text { translators }\end{array}$ & 3.53 & 3.33 & 3.96 & $\begin{array}{l}.022 \\
\text { Significant }\end{array}$ \\
\hline $\begin{array}{l}\text { Business } \\
\text { translators }\end{array}$ & 3.65 & 4.06 & 4.27 & $\begin{array}{l}<.001 \\
\text { Very highly } \\
\text { significant }\end{array}$ \\
\hline $\begin{array}{l}\text { Literary } \\
\text { translators }\end{array}$ & 4.10 & 3.75 & 3.83 & $\begin{array}{l}.458 \\
\text { Not significant }\end{array}$ \\
\hline
\end{tabular}

In other words, business translators satisfied with their income tend to see translator status in both senses as higher, and audiovisual translators satisfied with their income feel that their own work is appreciated more highly. Among literary translators, in contrast, satisfaction with one's income has no bearing on status perceptions.

Interestingly, these results differ in part from Dam and Zethsen's (see Section 2 above). While the number of low-status responses tended to decrease with higher income among one sub-group of Danish translators, high income levels were not accompanied by higher status in two other sub-groups. Among the Finnish respondents, income and satisfaction with one's income seem to play a more pronounced role. 


\subsection{Gender, age and work experience}

Gender, age and experience might appear prime candidates to affect one's perceptions. However, in our data, there are no statistically significant differences between male and female respondents' status rankings ( $p$ values .373 for status in general and .492 for the status of one's own work).

With regard to age, Dam and Zethsen $(2009$, p. 7) found that company translators' low-status rankings became more frequent with age, suggesting disillusionment. Interestingly, our results are different: when we compared the respondents aged 35 or younger $(n=105)$ with those aged 55 or older $(n=99)$ there were no statistically significant differences in perceived status of either the profession in general (means 2.52 vs. $2.65 ; p=.372$ ) or one's own work (means 3.78 vs. $4.08 ; p=.163$ ); as shown by the mean values, the older respondents actually reported higher status perceptions.

What we did discover was a statistical difference concerning work experience. The respondents who had worked within the translation industry for 21 years or longer perceived the value of their own work as higher (mean 4.08) than the respondents who had recently entered the industry, with a work experience of 5 years or less (mean $3.67 ; p=.008$ ). The difference only concerns the status of one's own work (for status in general, $p=.211$ ), but again it points to a different direction than previous research, toward professional self-esteem improving with increasing work experience.

\subsection{Educational background and working languages}

As illustrated in Table 2 above, almost $75 \%$ of the respondents had completed a master's degree. There were no statistically significant differences between the status rankings of those with a master's degree or higher and those with a lower degree; the $p$ values were .235 for status of the profession in general and .714 for the status of one's own work.

We next looked at whether the respondents had completed their degree in translation $(n=226)$, languages $(n=161)$ or some other discipline $(n=63)$. Translator training could either foster a stronger professional identity and hence more positive status perceptions or, as suggested by Ruokonen (2016), raise awareness about low status. Again, however, the differences were not significant: the smallest $p$ value was .101.

Working languages produced no statistically significant differences, either. We first considered the number of working languages ( 2 vs. 5 or more; lowest $p$ value .113), and then looked at the selection of working languages, comparing the respondents working only with the top three most frequent languages in the data (Finnish, Swedish and/or English) to the respondents whose repertoire also included rarer working languages such as Portuguese or Icelandic (lowest $p$ value .583).

\subsection{Professional wellbeing and job satisfaction}

The respondents' professional wellbeing and job satisfaction were gauged through three items:

- How frequently the respondents experienced negative, disturbing stress;

- How frequently the respondents had had to lower the quality of their output due to external factors such as deadlines; and

- How frequently the respondents had considered changing careers and leaving the translation industry within the past year. 
These items were only shown to those respondents currently working in the field of translation $(n=397)$. All three items produced statistically significant differences in the status perceptions of one's own work, as illustrated in Table 5 below.

Table 5: Dependencies between mean status perceptions and professional wellbeing

\begin{tabular}{|c|c|c|c|c|c|c|}
\hline \multicolumn{7}{|c|}{ Translator status in general } \\
\hline & \multicolumn{2}{|c|}{$\begin{array}{l}\text { Has experienced } \\
\text { negative stress }\end{array}$} & \multicolumn{2}{|c|}{$\begin{array}{l}\text { Has had to produce lower } \\
\text { quality due to external } \\
\text { circumstances }\end{array}$} & \multicolumn{2}{|c|}{$\begin{array}{l}\text { Has considered leaving } \\
\text { the translation industry }\end{array}$} \\
\hline & $\begin{array}{l}\text { Frequently } \\
\text { (1) }\end{array}$ & Rarely (2) & $\begin{array}{l}\text { Frequently } \\
\text { (3) }\end{array}$ & $\begin{array}{l}\text { Not at all } \\
(n=83)\end{array}$ & Frequently (4) & $\begin{array}{l}\text { Not at all } \\
(n=188)\end{array}$ \\
\hline Mean & 2.48 & 2.66 & 2.52 & 2.65 & 2.28 & 2.64 \\
\hline$p$ & \multicolumn{2}{|l|}{.085} & \multicolumn{2}{|l|}{.477} & \multicolumn{2}{|l|}{$\begin{array}{l}.004 \\
\text { Significant }\end{array}$} \\
\hline \multicolumn{7}{|c|}{ Status of one's own work } \\
\hline & \multicolumn{2}{|c|}{$\begin{array}{l}\text { Has } \quad \text { experienced } \\
\text { negative stress }\end{array}$} & \multicolumn{2}{|c|}{$\begin{array}{l}\text { Has had to produce lower } \\
\text { quality due to external } \\
\text { circumstances }\end{array}$} & \multicolumn{2}{|c|}{$\begin{array}{l}\text { Has considered leaving } \\
\text { the translation industry }\end{array}$} \\
\hline & $\begin{array}{l}\text { Frequently } \\
\text { (1) }\end{array}$ & Rarely (2) & $\begin{array}{l}\text { Frequently } \\
\text { (3) }\end{array}$ & $\begin{array}{l}\text { Not at all } \\
(n=83)\end{array}$ & Frequently (4) & $\begin{array}{l}\text { Not at all } \\
(n=188)\end{array}$ \\
\hline Mean & 3.77 & 4.11 & 3.78 & 4.17 & 3.50 & 4.12 \\
\hline$p$ & \multicolumn{2}{|l|}{$\begin{array}{l}.029 \\
\text { Significant }\end{array}$} & \multicolumn{2}{|l|}{$\begin{array}{l}.022 \\
\text { Significant }\end{array}$} & \multicolumn{2}{|l|}{$\begin{array}{l}<.001 \\
\text { Significant }\end{array}$} \\
\hline
\end{tabular}

(1) At least once a month or more often $(n=189)$

(2) A couple of times a year or not at all $(n=90)$

(3) At least once a month or more often $(n=157)$

(4) At least once a month or more often $(n=82)$

Those respondents who rarely experienced negative stress also had more positive perceptions of the status of their own work. Similarly, in the case of producing lower quality against one's choice, those respondents who rarely had to do so saw the status of their own work as higher.

Moreover, thinking about changing careers produced significant differences in the status of the profession in general. Those who had never thought about changing careers within the past year saw both the status in general and the status of their own work as higher than those who had considered doing so at least once a month: a natural correlation.

\section{Discussion and conclusions}

Our data indicate that, similarly to previous surveys, Finnish translators' general status perceptions are below the middle point, thus confirming and supporting a growing amount of empirical evidence on the subject. However, at the same time the data highlight that the respondents regard their own work as highly appreciated. This raises questions about how this sense of appreciation develops and why it does not carry over into the respondents' general status perceptions. Analyzing the open-ended items in the questionnaire on the factors affecting translator status and the measures and strategies for improving it should throw further light on these issues.

The respondents' perceptions of translator status in general appear rather resistant to variation: they are not dependent on the respondents' specialization, income level, work experience, educational background, 
working languages or authorization. It is particularly interesting that even specialization produces no statistically significant differences in either sense of the concept of 'status', considering that the respondents themselves ranked literary translators' status as higher than that of business or audiovisual translators.

In contrast to status in general, the respondents' perceptions of the status of their own work were sensitive to variation, notably in relation to professional wellbeing and job satisfaction. Satisfaction with one's income level (among business and audiovisual translators), stress, external pressure to produce lower quality and considerations about leaving the industry all produced statistically significant differences in status perceptions, indicating relevant correlations.

There are also correlations between one's own status and income level, but only within specific respondent groups such as freelancers and audiovisual translators. These respondents with below-median income judged the status of their own work significantly lower than respondents with above-median incomes.

Perhaps the most interesting result concerns the interconnections between the variables, which produce the following status profiles:

- Literary translators are believed to have the highest status out of these three professions. They earn the least, but their income level or (dis)satisfaction with it does not affect their perception of the status of their own work, which they see as high.

- Business translators are thought to have the second highest status. They also have the highest median income, and judge the status of their own work according to their income level and their (dis)satisfaction with their income.

- The audiovisual (AV) translators' profile emerges as the most negative. AV translators believe that they have the lowest status of these three professions. They also have the lowest income, and their status perceptions are relative to their income level.

It seems plausible that at least the audiovisual translators' profile reflects the recent developments in the Finnish translation market outlined earlier. In contrast, literary translators' relatively high status and its independence of income is probably a trend not limited to Finland. For example, in her studies on Israeli translators, Rakefet Sela-Sheffy has drawn attention to literary translators' low fees (Sela-Sheffy, 2010, p. 136) and to how particularly elite translators enhance their status by means of a rhetoric that conceptualizes their work as a vocation and a form of art rather than a means for earning a living (Sela-Sheffy, 2006, 2008; Sela-Sheffy, 2010, p. 136-137; Sela-Sheffy, 2016, p. 58).

On the whole, our results highlight interesting dependencies between status perceptions and translators' working conditions and professional wellbeing. The results also suggest further avenues to explore to better understand the different concepts of status and the various factors affecting status perceptions. Perhaps, ultimately, research can contribute to resolving the conflict between translators' own work being appreciated and the profession at large being undervalued. 


\section{References}

Abdallah, K. (2007). Tekstittämisen laatu - mitä se oikein on? [Subtitling quality what is it?] In R. Oittinen \& T. Tuominen (Eds), Olennaisen äärellä: johdatus audiovisuaaliseen kääntämiseen (pp. 272-293). Tampere: Tampere University Press.

Antinjuntti, K., Boman, H., Baran, K. \& Gorschelnik, H. (2014, June 18). Käännös- ja tulkkauspalveluiden kilpailutus vääristää käännös- ja tulkkausalan kehitystä ja vinouttaa markkinoita. Työministeri Ihalaisen pyytämä selvitys käännös- ja tulkkauspalveluiden kilpailutuksesta 18.6.2014. SKTL ja KAJ. (Finnish translator associations' report to the Minister of Labor on how competitive tendering distorts the development of the translation and interpreting industry and skews the market) Retrieved May 5, 2017 from https://sktl-fibin.directo.fi/@Bin/330061e0a408e08f469b9f98ac18fa37/1493962459/applicati on $/$ pdf $/ 404228 / \mathrm{Ka} \% \mathrm{CC} \% 88 \mathrm{a} \% \mathrm{CC} \% 88 \mathrm{nno} \% \mathrm{CC} \% 88 \mathrm{salan} \% 20$ kilpailutuksesta_2 014_06_18_Ihalaiselle.pdf

American Psychological Association (2012, March 8). APA survey finds feeling valued at work linked to well-being and performance. Press release. Retrieved May 5, 2017, from http://www.apa.org/news/press/releases/2012/03/wellbeing.aspx

Dam, H. V. \& Zethsen, K. K. (2008). Translator status. A study of Danish company translators. The Translator, 14(1), 71-96.

Dam, H. V. \& Zethsen, K. K. (2009). Who said low status? A study on factors affecting the perception of translator status. Journal of Specialised Translation, 12, 2-36. Retrieved May 5, 2017 from http://www.jostrans.org/issue12/ art_dam_zethsen.pdf

Dam, H. V. \& Zethsen, K. K. (2011). The status of professional business translators on the Danish market: a comparative study of company, agency and freelance translators. Meta: Translators' Journal, 56(4), 976-997.

Dam, H. V. \& Zethsen, K. K. (2012). Translators in international organizations. A special breed of high-status professionals? Danish EU translators as a case in point. Translation and Interpreting Studies, 7(2), 211-232.

Dam, H. V. \& Zethsen, K. K. (2013). Conference interpreters - the stars of the translation profession? A study of the occupational status of Danish EU translators as compared to Danish EU translators. Interpreting, 15(2), 229-259.

Dam, H. V. \& Zethsen, K. K. (2016). 'I think it is a wonderful job.' On the solidity of the translation profession. The Journal of Specialised Translation, 25, 174-187. Retrieved May 5, 2017, from http://www.jostrans.org/issue25/art_dam.pdf

Ganzeboom, H. B. G. \& Treiman, D. J. (2003). Three internationally standardised measures for comparative research on occupational status. In J. H. P. HoffmeyerZlotnik \& C. Wolf (Eds), Advances in cross-national comparison. A European working book for demographic and socio-economic variables (pp. 159-193). New York: Kluwer Academic Press.

Gentile, P. (2013). The status of conference interpreters: A global survey into the profession. Rivista internationale di tecnica della traduzione: International Journal of Translation, 15, 63-82. Retrieved May 5, 2017, from http://hdl.handle.net/10077/10608

Hietamaa, T. (2014). Kahden kerroksen kääntäjiä: Kvantitatiivinen työolokysely avkääntäjien ansioista alan muutosten käännekohdassa 2010-luvun alussa. [Translators of two tiers: Quantitative survey of audiovisual translators' income at the turning point in the field in the early 2010] Retrieved May 5, 2017, from http://www.journalistiliitto.fi/wp-content/uploads/old/av-kaantajien_tyoolot__tutkimusraportti.pdf

Katan, D. (2009). Translation theory and professional practice: a global survey of the great divide. Hermes - Journal of Language and Communication Studies 42, 111-153.

Leppänen, S., Pitkänen-Huhta, A., Nikula, T., Kytölä, S., Törmäkangas, T., Nissinen, K., ...Jousmäki, H. (2011). National survey on the English language in Finland: Uses, meanings and attitudes. Studies in variation, contacts and change in 
English 5. Retrieved May 5, 2017, from http://www.helsinki.fi/varieng/journal/ volumes $/ 05$

Mäkisalo, J. (2006). Kuinka paljon käännöksiä luetaan? Lukupäiväkirjan esitutkimus. [To what extent do people read translations? A preliminary study of reading journals] Virittäjä, 110, 250-259.

Pym, A., Grin, F., Sfreddo, C. \& Chan, A. L. J. (2012). The status of the translation profession in the European Union. Studies on translation and multilingualism 7/2012. Luxembourg: Publications Office of the European Union. Retrieved May 7, 2017 from http://ec.europa.eu/dgs/translation/publications/studies/translation _ profession_en.pdf

Ruokonen, M. (2013). Studying translator status: three points of view. In M. Eronen \& M. Rodi-Risberg (Eds.), Haasteena näkökulma: Point of view as challenge. VAKKI Publications 2 (pp. 327-338). Vaasa: University of Vaasa. Retrieved from http://www.vakki.net/publications/2013/VAKKI2013_Ruokonen.pdf

Ruokonen, M. (2016). Realistic but not pessimistic: Finnish translation students' perceptions of translator status. Journal of Specialised Translation, 25, 188-212. Retrieved May 5, 2017 from http://www.jostrans.org/issue25/art_ruokonen.pdf

Ruokonen, M. (forthcoming). To protect or not to protect: Finnish translators' perceptions on translator status and authorisation. HERMES - Journal of Language and Communication in Business.

Ruokonen, M., Svahn, E. \& Salmi, L. (2016). Panel 10. Translator status and identity: constructed and experienced boundaries of the translation profession. [Abstract] EST Congress 2016, Aarhus, Denmark. Retrieved May 5, 2017, from http://bcom.au.dk/research/conferencesandlectures/est-congress-2016/panels/ panel-10-translator-status-and-identity-constructed-and-experienced-boundariesof-the-translation-profession/

Salmi, L. (2010). 'Translations around us' - the amount of translated text in everyday life. MikaEL 4, 1-15. Retrieved May 5, 2017, from https://sktlfi.directo.fi/@Bin/40746/Salmi_MikaEL2010.pdf

Scott, J. (2015). Status (social status). A dictionary of sociology ( $4^{\text {th }}$ edition, online). Oxford: Oxford University Press.

Sela-Sheffy, R. (2006). The pursuit of symbolic capital by a semi-professional group: the case of literary translators in Israel. In M. Wolf (Ed.), Übersetzen translating - traduire: towards a social turn (pp. 243-252). Wien \& Berlin: LIT Verlag.

Sela-Sheffy, R. (2008). The translators' personae: marketing translatorial images as pursuit of capital. Meta: Translators' Journal, 53(3), 609-622.

Sela-Sheffy, R. (2010). 'Stars' or 'professionals': the imagined vocation and exclusive knowledge of translators in Israel. In O. Diaz Fouces \& E. Monzó (Eds), MonTI 2: Applied Sociology in Translation Studies (pp. 131-152). Alicante: Publicaciones de la Universidad de Alicante. Retrieved May 5, 2017 from http://www.tau.ac.i1/ rakefet/papers/RS-MonTI_2010.pdf

Sela-Sheffy, R. (2016). Elite and non-elite translator manpower: The nonprofessionalised culture in the translation field in Israel. Journal of Specialised Translation, 25, 54-73. Retrieved May 5, 2017 from http://www.jostrans.org/ issue25/art_sela.pdf

Setton, R. \& Guo Liangliang, A. (2011). Attitudes to role, status and professional identity in interpreters and translators with Chinese in Shanghai and Taipei. In R. Sela-Sheffy \& M. Shlesinger (Eds), Identity and status in the translational professions (pp. 89-117). Amsterdam/Philadelphia: John Benjamins.

Statistics Finland (2015a, June 8). Population structure on 31.12.2015. Retrieved May 5, 2017 from http://www.stat.fi/tup/suoluk/suoluk_vaesto_en.html

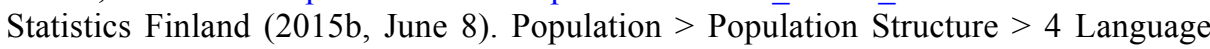
according to age and sex by region 1990-2015. Retrieved May 5, 2017, from http://pxnet2.stat.fi/PXWeb/pxweb/en/StatFin/?rxid=bb5ec89f-df07-4624-8b45f207b264a469.

Statistics Finland (2015c, December 21). Number of persons at risk of poverty decreased slightly in 2014. Retrieved May 5, 2017 from http://www.stat.fi/til/tjt/2014/01/tjt_2014_01_2015-12-21_tie_001_en.html.

Translation \& Interpreting Vol 10 No 1 (2018) 
Treiman, D. J. (2001). Occupations, stratification, and mobility. In J. R. Blau (Ed.), The Blackwell companion to sociology (pp. 287-313). Malden, Mass./Oxford: Blackwell.

Tuominen, T. (2015). Subtitlers going professional: the professional project and virtual community of Finnish subtitlers. In A. Liimatainen, J. F. Schopp \& T. Tuominen (Eds), mTm Journal Special Issue: Translation Goes Professional. Contributions from the Tampere School on the Occasion of the $80^{\text {th }}$ Birthday of Justa Holz-Mänttäri, 103-126.

Volti, R. (2008). An introduction to the sociology of work and occupations. Los Angeles: Pine Forge Press.

Wadensjö, C. (2011). Status of interpreters. In Y. Gambier \& L. van Doorslaer (Eds.), Handbook of Translation Studies 2 (pp. 140-145). Amsterdam/Philadelphia: John Benjamins. 